\title{
"Porphyries" from Russia and Sweden used in St Petersburg and Russian "porphyry" used in Paris: misuse of a geological term for some possible candidate as a Global Heritage Stone Resource
}

Institute of Earth Sciences, St Petersburg State University, University embankment 7-9,St Petersburg, 199036 Russia. E-mail: andreygleb@ mail.ru

(Received July 22, 2014; Revised accepted September 22, 2014)

The term "porphyry" has a specific geological meaning but has been used freely by sculptors and art historians to name many types of stone that are not, geologically, porphyries. "Porphyries" have been associated with nobility and Imperial Monuments since Roman times. This paper discusses some examples from Karelia in Russia and from Sweden used in St Petersberg and the use of Russian Shoksha "porphyry" in Paris, France. It highlights several types of stone that have been referred to as porphyries but are not. The Shoksha stone has been of architectural and artistic importance both nationally and internationally for some 300 years. This might qualify it as a candidate for Global Heritage Stone Resource status.

\section{Introduction}

The term "porphyry" has a specific geological meaning but has been used freely by sculptors and art historians to name many types of stone that are not, geologically, porphyries just as the term "granite" has been used for a wide variety of durable stones that take a good polish. This paper discusses some examples from St Petersburg in Russia and from Sweden.

Description of colour is also an issue because both "purple" and "scarlet" were both used in referring to colours of tunics and robes of nobles in Ancient Rome. It is understandable that stone in the continuum of colours from "purple" to "scarlet" should have become associated with nobility and Imperial monuments.

The most famous antique ornamental porphyry came from Gebel Dokhan in the Province of Egypt in the Roman Empire (Fig. 1) and has attracted names such as "Red Antique" and "Imperial" porphyry. Sculptures and the busts of Roman Emperors, sarcophagi (Fig. 2) and other masterpieces were cut from this stone, especially in extensive quarrying operations between the $1^{\text {st }}$ and the $4^{\text {th }}$ centuries A.D. From a petrographic point of view, this rock is a dacite-andesite porphyrite
(Price, 2007, p. 203) which contains feldspar phenocrysts in a fine grained or glass-like groundmass (Fig. 3). Fine-grained piemontite gives colour to the stone.

\section{Porphyries in St Petersburg}

At the end of $18^{\text {th }}$ century and during the $19^{\text {th }}$ century "porphyry" became fashionable in decorating the facades and interiors of palaces and mansions in St Petersburg.

The first to be used was the Schoksha porphyry (Bulakh et al., 2010, 2014). In 1801, this stone was used in friezesin the main façade of St Michael Castle (Fig. 4), a residence of the Russian Emperor Paul I. The same stone was used to design the interior of St Isaac's Cathedral (1818-1848). Steps to the altar and the bottom part of the iconostasis were hewn out of dark-red Schoksha stone. The same rock type was used for cornices topping walls as well as in the wide frieze of that stone that fringes the periphery of the floor of the cathedral. A bust to Auguste de Montferrand (Fig. 5), the architect of St Isaac's Cathedral, stands inside. The sculptor A. Foletti created the bust from the many kinds of stones that were used by Montferrand in building the cathedral. The face was carved from white Carrara Marble,

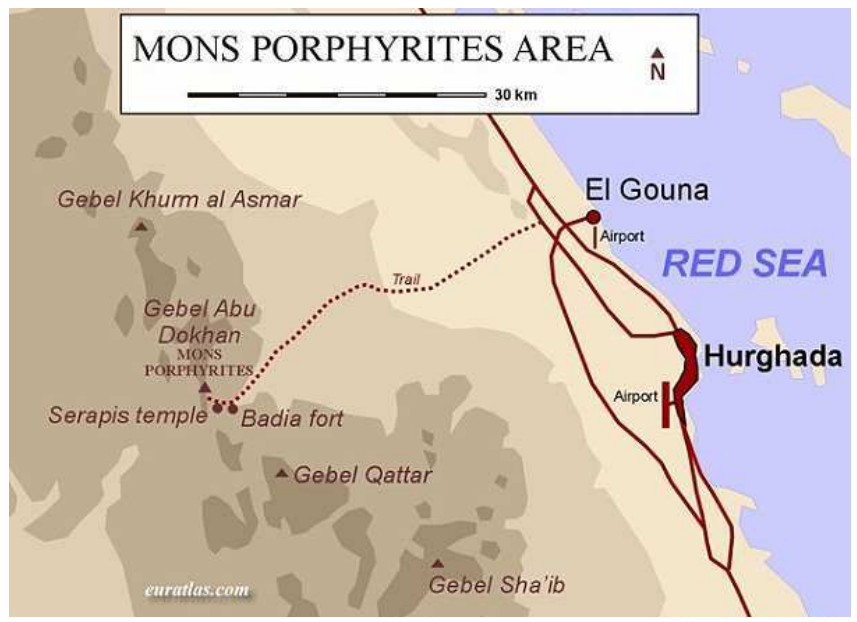

Figure 1. Location of Gebel Abu Dakhan. 

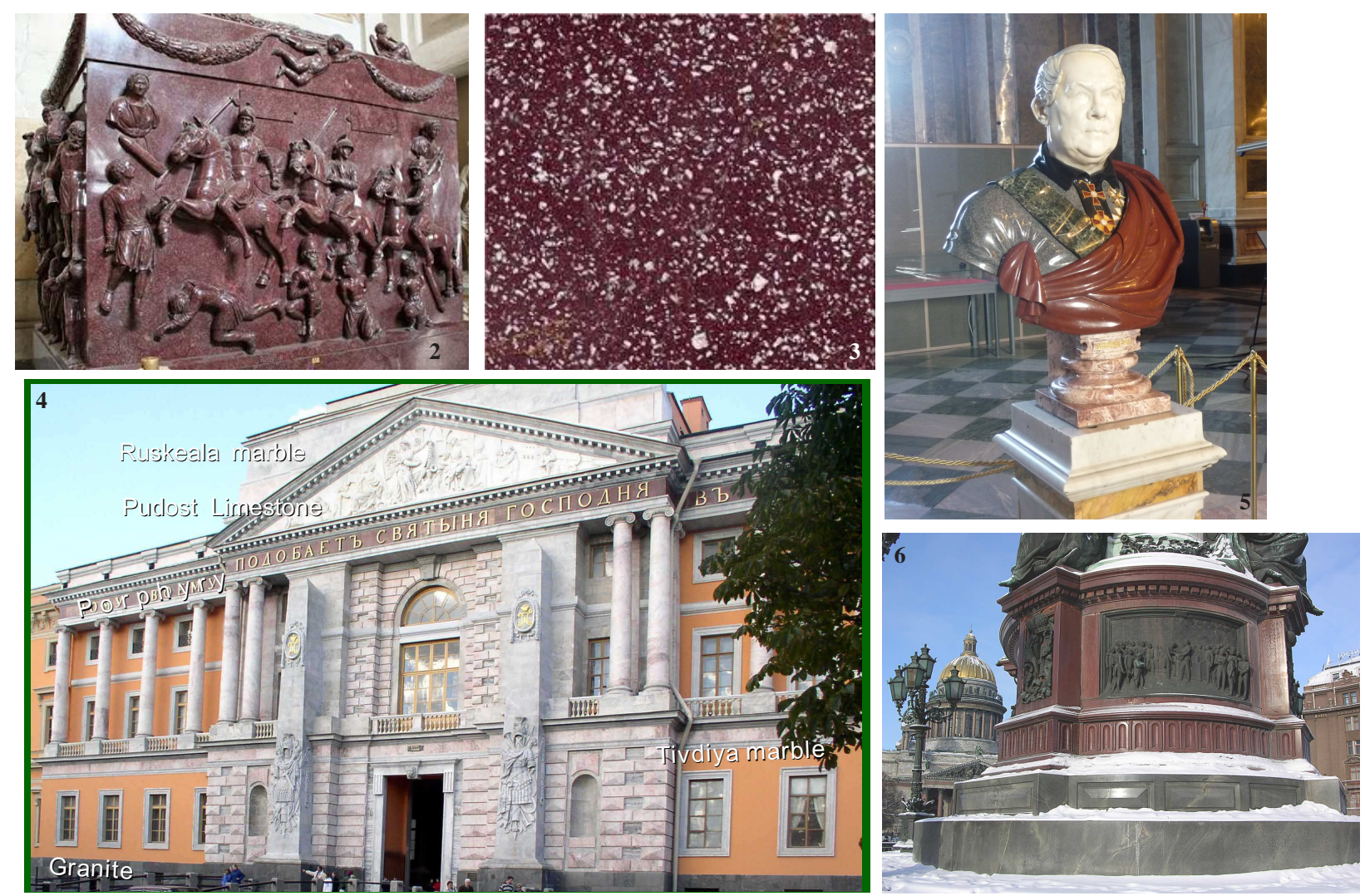

Figures 2-6. (2) Sarcophagus of St Helen. Imperial porphyry from Egypt. (3) Texture of imperial porphyry. (4) Red porphyry-like stone in facade (St. Petersbury, St Michael Temple, 1797-1800). (5) Porphyry-like stone in the cloak of A. Montferrand . (6) Monument to Nicholas I. Red porphyry-like stone is a frame for high reliefs

the hair from grey granite, the collar of the uniform from slate, the cloak from crimson Schoksha stone, the cordon of green marble, and the orders from yellow Siena marble and also crimson Shoksha stone. Pink Tivdiya Marble from Onega Lake, Karelia, Russia, served for the pedestal of the bust.

The most memorable example of the use of this stone is the pedestal of the Tsar Nicholas I monument (Fig 6). Montferrand designed the monument and decorated it with red Schoksha porphyry, pink Rapakivi Granite, grey Serdobol Granite, and white Carrara Marble. The sculptor, P. Klodt, created the monument in an equestrian form.

Superficially, Schoksha "porphyry" closely resembles the antique imperial porphyry from Gebel Dakhan but is, in fact, a Proterozoic quartzite. The only source is located in the FennoScandian Shield, on the south-east coast of Lake Onega (Fig. 7). Many color varieties of Schoksha quartzite have been quarried here since the $18^{\text {th }}$ century. The stone is layered (Figs. 8, 9) and fine grained (Fig. 10)

Secondly, there are many and varied examples of "porphyry" vases (Fig. 11), craters, amphora, bowls, obelisks, table-desks and other goods in collections of the State Hermitage (Mavrodina, 2007). These were manufactured by Russian masters at the Peterhof, Yekaterinburg and Kolyvan lapidary factories from 1790-1860. The majority of these masterpieces were manufactured from greyish-violet and grey stone taken from the River Korgon, in the Altai Mountains in Siberia. This is a fine-grained almost glass-like rock sometimes with flow texture and with fine phenocrysts of feldspar and quartz together with chalcedony and has been described as a "silicified porphyry"
(Samsonov and Turinge, 1984, p.158-159), but the meaning of the word "porphyry", in this context, has not been stated clearly.

\section{Swedish"porphyries" in St Petersburg}

However, "porphyries" were also brought to St. Petersburg from elsewhere. Three stone vases that stand in the city of St Petersburg were worked by the Royal Porphyry manufacturing factory in Älvdalen, Sweden in $19^{\text {th }}$ century. A pair of greyish-black vases (craters) arrived in 1830s. They firstly stood, together with two bronze lions,on the flanks of granite staircase to the Winter Palace (a residence of Russian Emperors) on the Neva River (Fig. 13). In 1914-1916, these vases were moved to flank another granite staircase, between the Admiralty and the Bronze Horseman (Bulakh et al., 2014). The "porphyry" used is, geologically,a coarse-grained diabase (Bulakh et al., 2006) locally known as Åsbo diabase after a village near the extraction site in Sweden (Hjelmquist, 1982). The vases are hollow and stoppered but broke into many pieces due to internal accumulation and freezing of water in the past decade. The Russian Master A. Androkhanov restored them, and they were returned to their place in May 2014 (Fig. 14).

The third vase was presented to the Russian Emperor Nicholas I by King Carl XIV Johan Bernadotte of Sweden. It was placed in the Summer Garden in 1839 and consists of four parts (Fig. 15), the neck, body, stem, and plinth, cut from Garberg granite (Bulakh et al., 2006; Hjelmquist, 1982). In 1825, this stone was used to manufacture the famous Rosendal vase in Stockholm. The total height of the vase in the Summer Garden with its pedestal is 4.85 metres. The pedestal is made of Blyberg porphyry, and "porphyry" is a geologically 

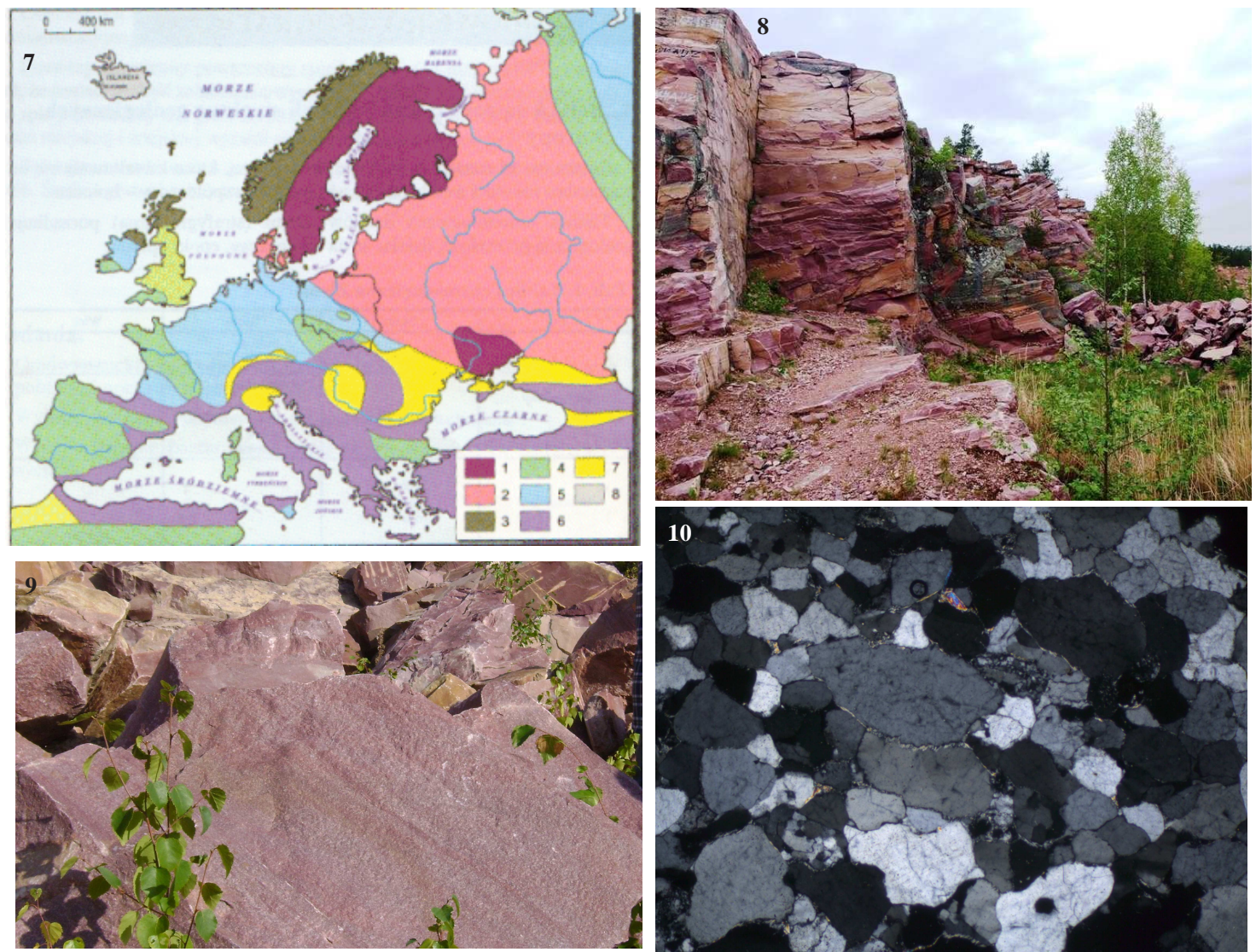

Figures 7-10. (7) Location of the Schoksha Deposit. 1-8 - different tectonic zones of Europe. (8) The Schoksha quarry. (9) Schoksha quartzite Sedimentary layering. (10). Schoksha quartzite. Microscopic structure.

appropriate term here (Hjelmquist, 1982). In the frost of January 2008, this vase developed a crack and fell apart due to gradual accumulation of water in original natural cracks in the stone and inside the vase (Bulakh et al., 2011). Carl XIV had planned to present a pair of vases, but one of the two manufactured vases cracked just after it was produced, showing that weaknesses were present at the outset although, even so, the vase remained intact for many years. This vase was restored by A. Androkhanov (Fig. 16) and put back in position in May 2013.

\section{Stone of the Napoleon's sarcophagus in Paris}

The use of Russian "porphyry" is not limited to the Russian
Federation. As is well known, the tomb of Napoleon I Bonaparte is located in the central crypt of the Église du Dome church at the Hotel des Invalides, in the City of Paris. The remains of the Emperor, inside the sarcophagus, are protected by six concentric coffins, made from different materials, including mahogany, ebony, and oak, one inside the other. The tomb itself (Fig. 12) was crafted in red "porphyry" placed on a green "granite" base.It is circled by a crown of laurels with inscriptions, which act as reminders of the Emperor's great victories (http://www.paris-france.me.uk/napoleon's_tomb.htm.)

This red porphyry is, in fact, Schoksha quartzite. Moscow, the capital of Russia, is listed between laurels in a circle on the monument. Tsar Nicholas I is reputed to have said that this was strange fate for Emperor Napoleon because he lost his glory in a struggle with
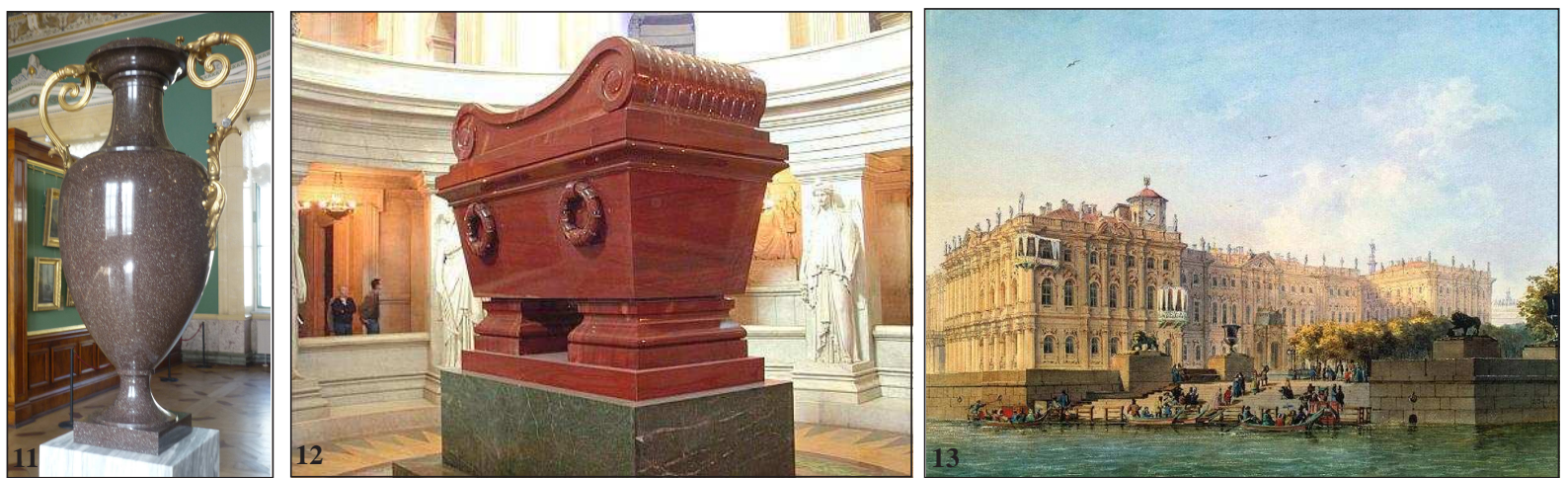

Figures 11-13. (11) Korgon porpyry Vase. The Hermitage. (12) Napoleon's sarcophagus. (13) Black Swedish vase near the Winter Palace. 1847. Water-colour, by L.Bonshtedt 

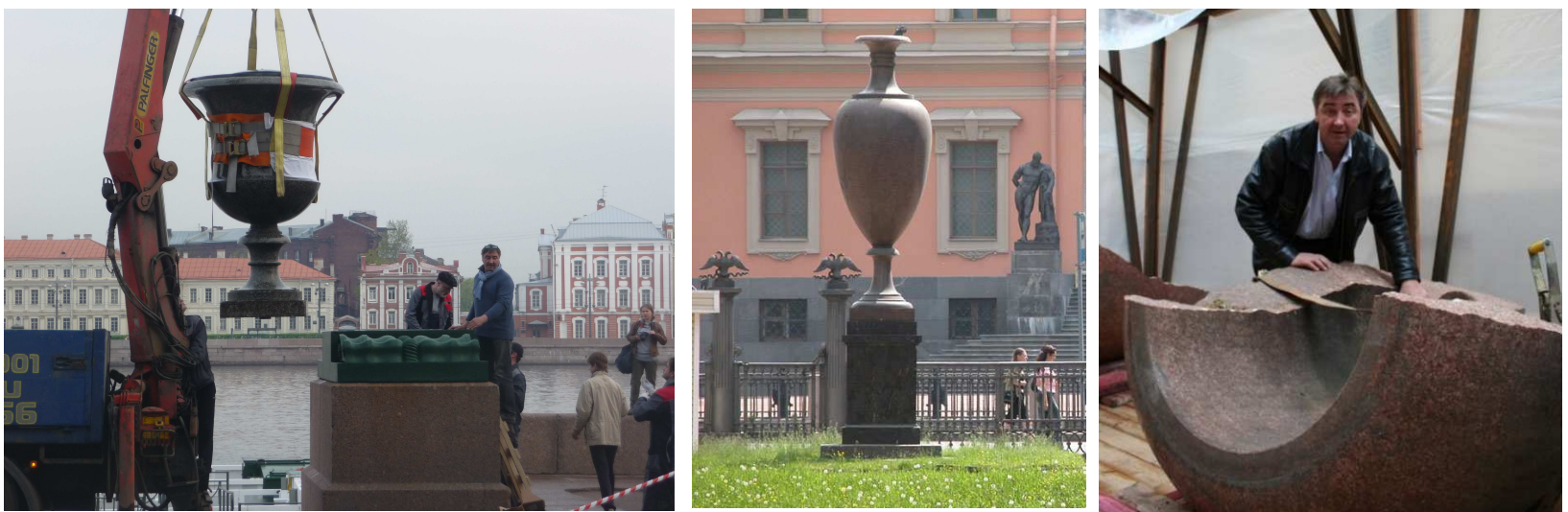

Figures 14-16. (14) A black Swedish vase being returned after restoration. May 11, 2014. (15). A pink Swedish vase in the Summer Garden. 2007. (16) Master A. Androkhanov and a split pink Swedish vase

Russia but Russia presented stone for his tomb. The reality was that architect Luis Visconti was not able to find large blocks of antique Egyptian porphyry from the old quarries and selected Schoksha quartzite as an alternative. A special quarry was developed to secure massive stone blocks of raspberry color with almost unnoticeable sedimentary layering. Twenty seven blocks totaling forty tons were sent to France in 1847 . The largest was about $4 \times 2 \times 0.8$ meters in size.

\section{Conclusions}

The examples presented in this paper highlight the misuse of the term "porphyry" in old literature on history of art. In books on art and architecture it can refer to many different types of rock of superficially similar appearance and properties. Many of these are not, geologically, porphyries. Careful examination of old documents and petrographical examination of the stone in monuments and sculpture are needed to properly identify stone required for repairs.

Secondly the examples demonstrate the cultural importance of the "porphyries" from Karelia and the Urals both within and outside the Russian Federation as well as those imported from Sweden. The artistic and architectural significance of the Shoksha quartzite over the past 300 years might qualify it as a candidate for Global Heritage Stone Resource status.

\section{Acknowledgements}

The paper went through an extensive editing by B. Marker and B. Cooper in preparation for publication. The author greatly thanks them for their kind help. The author visited the Natural History Museum in Stockholm and Älvdalen. He again thanks Mr Jan Olav Nyström, Mrs Monica Sjö, Mr Jan Westling, and Mr Alex Schebanov for their assistance.

\section{References}

Bulakh, A.G., Kondratjeva, V.V., Antonov, A.A. 2006. The vases from Swedish stone in St Petersburg // Relikvia. No 15, pp. 1014. In Russian.
Bulakh, A.G., Abakumova, N.B., Romanovsky, J.V. 2010. St Petersburg. The History in Stone. St Petersburg. St Petersburg University Press. 173 p.

Bulakh, A.G., Abakumova, N.B., Romanovsky, J.V. 2014. St Petersburg Stone Guide. ${ }^{1}$ 1-5. www. Available on-line: http:// www. Bulakh_Stone_Guide_pdf

Bulakh, A., Nesterov, E., Choi, S.-W., Vlasov D. 2011. Inspection results of the Swedish Stone Vase in the St Petersburg Summer Garden. Journal of Conservation Sciences. Korea. March. Vol. 21. No 1. pp. 123-126.

Hjelmquist, S. 1982. The porphyries of Dalarna, Central Sweden.Sveriges Geologiska Un-dersoking. Serie C. Nr. 782. Avhandlingar och Uppsaster Arsbok. 75. Nr. 3. Uppsala. 27 p.

Mavrodina, N.M. 2007. The Art of Russian Stone Carvers. $18^{\text {th }}-19^{\text {th }}$ Centuries. The catalogue of the Collection. St Petersburg. The State Hermitage Publishers. 559 p. In Russian.

Price, M. T. 2007. The Sourcebook of Decorative Stone. Quintet Publishing Limited. 288 p.

Samsonov, J.P. and Turinge, A.P. 1984. Gems of the USSR. Moscow. Nedra. 335 p. In Russian.

Websites

City of Paris. Napoleon's Tomb. http://www.paris-france.me.uk/ napoleon's_tomb.htm

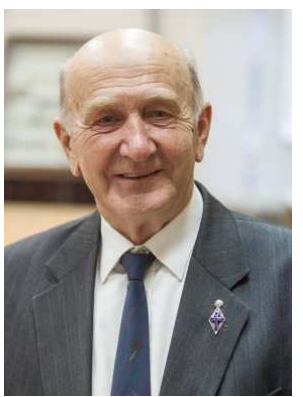

A.G. Bulakh born on 29 March 1933 in St. Petersburg, Russia. Prof. Bulakh is a Professor of mineralogy in St. Petersburg State University. He obtained Ph.D during the year 1962 and D.Sc in 1979. He has authored monographs and textbooks on mineralogy and books on using natural stone in architecture of St. Petersburg 